\title{
Analysis of Serbian Market Concerning Online Corporate Learning
}

\author{
Radojka Krneta \\ Technical Faculty, University of \\ Kragujevac, Cacak, Serbia
}

rkrneta@gmail.com

\author{
Vladimir Zocevic \\ Agromehanika Service, \\ Cacak, Serbia
}

obilics@yahoo.com

\begin{abstract}
The purpose of this paper is to analyze an investigation into current state and needs of the Serbian business market from the aspect of conversion of traditional corporate trainings and meetings to modern means of communication and education. In this way we were specifically focused on application of online training and videoconference system in the above process. The objective of this paper is to examine how informed companies are about the technology and its introduction into everyday business practice. The research underlines the results of the analyses concerning the practical aspect of videoconferences in Serbian companies and foreign ones operating through branches in Serbia.
\end{abstract}

Keywords: corporate learning, online learning, videoconferences, virtual trainings, virtual meetings

\section{Introduction}

The exponential growth in number of available information, which is one of essential characteristics of modern business, has induced an increase in recent learning requirements. Daily inflow of new information and continuous obsolescence of present ones as well as constant changes in business environment irretrievably results in the necessity for staff education. This enables companies to keep pace with changed circumstances and deliver good performance.

Training staff occasionally and covering only the theoretical aspect of education usually proves insufficient. Surveys carried out in the USA in 2009, suggest that $90 \%$ of employees soon forget the information and skills acquired by traditional methods (White Paper: Real Sales Success Delivered Virtually, 2009). Continuous education that includes modern technological innovations is currently being in the focus (Rosenberg, 2008). Permanent and quality education on the one hand, and cost reduction on the other are the two opposite objectives which can be reconciled and united. Namely, Internet enables education of a large number of employees whereby the increase

Material published as part of this publication, either on-line or in print, is copyrighted by the Informing Science Institute. Permission to make digital or paper copy of part or all of these works for personal or classroom use is granted without fee provided that the copies are not made or distributed for profit or commercial advantage AND that copies 1) bear this notice in full and 2) give the full citation on the first page. It is permissible to abstract these works so long as credit is given. To copy in all other cases or to republish or to post on a server or to redistribute to lists requires specific permission and payment of a fee. Contact Publisher@,InformingScience.org to request redistribution permission. in the number of candidates makes minor increase in companies' expenses. Furthermore, the use of Internet enables every employee or group of employees to get the exact part of the educational material intended for them, while, at the same time, there is no increase in costs (Meister, 2007). In terms of quality and costs, videoconferences and online courses are the most applied means of education. Numerous advantages arising 
from these forms of education make videoconferences and distance learning courses more attractive, thus suppressing traditional learning methods (Knowledge in Organizations, 1997).

These forms of contemporary education have been increasingly introduced in Serbia in recent times. However, modern forms of education are mostly related to large, primarily foreign companies with established branches in Serbia. It is the strong inclination of companies to change current trend of low investing in staff education and introduce new forms of education that raises hope for brighter prospects in the Serbian business market (Njeguš \& Veljović, 2004).

In order to gain deeper insight into companies' attitude towards corporate learning and their knowledge and experiences in videoconferencing and online courses, and aiming at perceiving the companies' initiatives regarding the introduction of videoconferences and online courses into business practice, we have carried out an investigation into the attitude towards corporate learning and modern education forms among Serbian companies and foreign ones operating in the Serbian territory.

\section{An Investigation into Current State and Needs of the Serbian Business Market from the Aspect of Corporate Learning}

\section{Research Structure}

Main objectives of our research are:

- to study companies' attitudes towards corporate learning,

- to study possible conversion of traditional forms of meeting to modern means of communication and education, with special reference to the application of videoconferences in the processes,

- to study how knowledgeable companies are about specificities of videoconferencing, and their attitude towards their potential introduction into everyday business practice.

Major research variable, which is subject to change, refers to the application of different types of online education and videoconferencing in business practice. It includes two aspects of videoconferencing implementation - qualitative (mode of implementation of online education and videoconferences, i.e. online courses, videoconference-based lectures, virtual training and simulation, virtual meetings) and quantitative (frequency of different types of implementation of education, and the application of the systems). Independent or unchanging variables include a number of issues, i.e. demographic (major activity and a company's seat), environmental (place of work and the working environment), socio-demographic (sex, age, a respondent's place of residence), psychological (a respondent's attitudes to learning and education, and his/her value system) and educational (education degree, how knowledgeable he/she is about online education).

In our research, the major hypothesis has been that companies in the Serbian education market give modest allocations for training of employees, which most commonly occurs only when the situation calls for it, even in cases when their attitude to education is positive. In addition, we also assumed that the majority of companies do not take up videoconferencing in their business, nevertheless, understanding advantages arising from the application of the method they plan to introduce it when the resources are provided.

Classic and online survey methods were applied for the purpose of gathering data. The majority of queries put before the survey respondents involved choosing between one or more answers. The conception of a number of queries included the descriptive method, whereas in other cases 
respondents were given assessment scale with grading option from 1 to 5 whereby the scale referred to their evaluation of current state in their company.

Structure of instrument is as follows: there are 35 queries (items) totally, 1 from that is in the form of open queries, 32 from that are in the form of closed queries with multiple choice or alternative choice and 2 queries are in the form of assessment scale. Queries are arranged into two thematic blocks.

The data processed by the statistic software.

The data were subjected quantitative analyses and the results are presented via a description method, tables and/or charts which are derived from the statistic software.

The survey included 22 domestic companies and 8 foreign ones operating through branches in the region of Serbia. In the name of the company in $40 \%$ of cases the answers are given managers $(12 / 30)$, while in $60 \%$ of cases did the operating workers (those 18). The survey included different branches of economy, which also helped us to perceive general state of affairs in economy of the country (Table 1).

Table 1. Respondents structure

\begin{tabular}{|l|r|r|}
\hline \multicolumn{1}{|c|}{ FIELD OF WORK } & TOTAL & \multicolumn{1}{c|}{ \% } \\
\hline Services & 3 & 10 \\
\hline Import, Delivery Services and Sale, Representation & 9 & 30 \\
\hline Production & 7 & 23.3 \\
\hline Telecommunication and Information Systems & 6 & 20 \\
\hline Banking, Financing and Insurance & 5 & 16.7 \\
\hline \multicolumn{1}{|c|}{ TOTAL NUMBER OF RESPONDENTS: } & $\mathbf{3 0}$ & $\mathbf{1 0 0 \%}$ \\
\hline
\end{tabular}

The research was conducted from December 2008 to September 2009 via a conventional and online poll.

\section{Results}

Before studying companies' attitudes to online education and videoconferencing, we had to investigate their attitude toward education in general.

Almost all respondents (96.7\%) regard education a necessity that has major influence on business, whereas only $3.3 \%$ of respondents consider it as a necessary evil that increases business costs. The latter pointed out that their companies do not invest in education, while the rest gave different answers (Figure 1). 


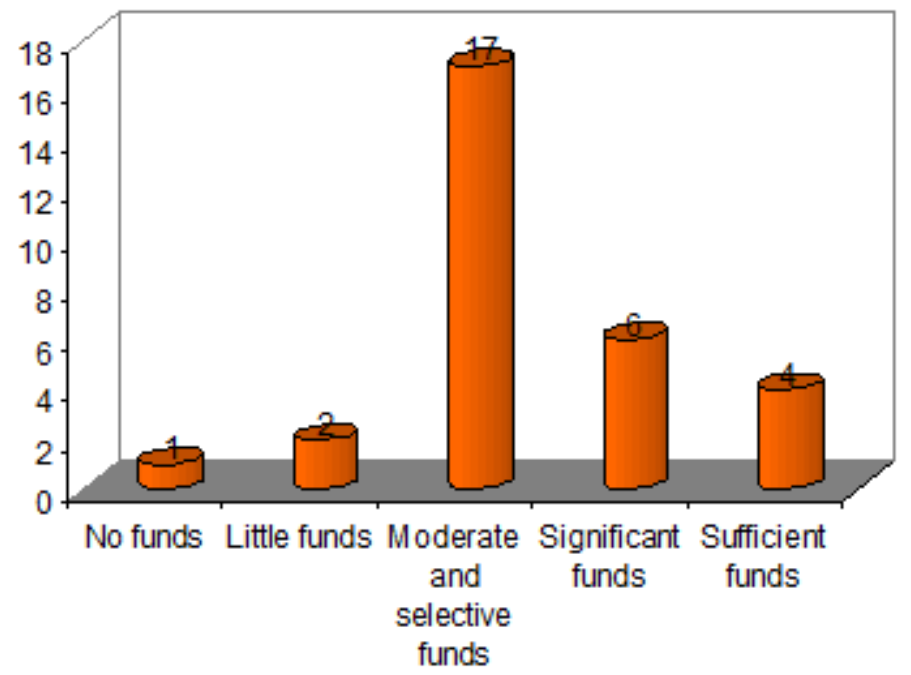

Figure 1: Resource allocation

The facts that $96.7 \%$ of respondents believe that education provides broader benefits and that only $10 \%$ of respondents report on modest allocations their companies give to staff education enable us to draw solid conclusion that Serbian companies are inclined to following global education trends and understand the importance of continuous education of employees.

Despite the collective awareness of necessity of permanent-based staff education, Serbian companies are facing hard times for running business due to the social and economic crisis, therefore only few companies can boast of having staff education departments (30\%, 9 companies), whereas $53.3 \%$ of companies assign the issue of staff education to only one person. Other companies neither have a department nor a person in charge of education of employees $(16.7 \%)$. The fact that only in 5 out of 9 departments $(55.5 \%)$ education is the major activity is the indicative of the crisis. In the rest ( 4 departments) it is considered an additional activity. The same goes for companies which instead of a department employ a person in charge of education. Education is occasional or continuous in 28 companies $(93.3 \%$ ), whereas $6.7 \%$ of the surveyed companies do not devote any attention to the process. Fifteen companies in the former group (53.6\%) educate their employees, 12 (42.9\%) companies educate both the employees and the clients, whereas 3.5

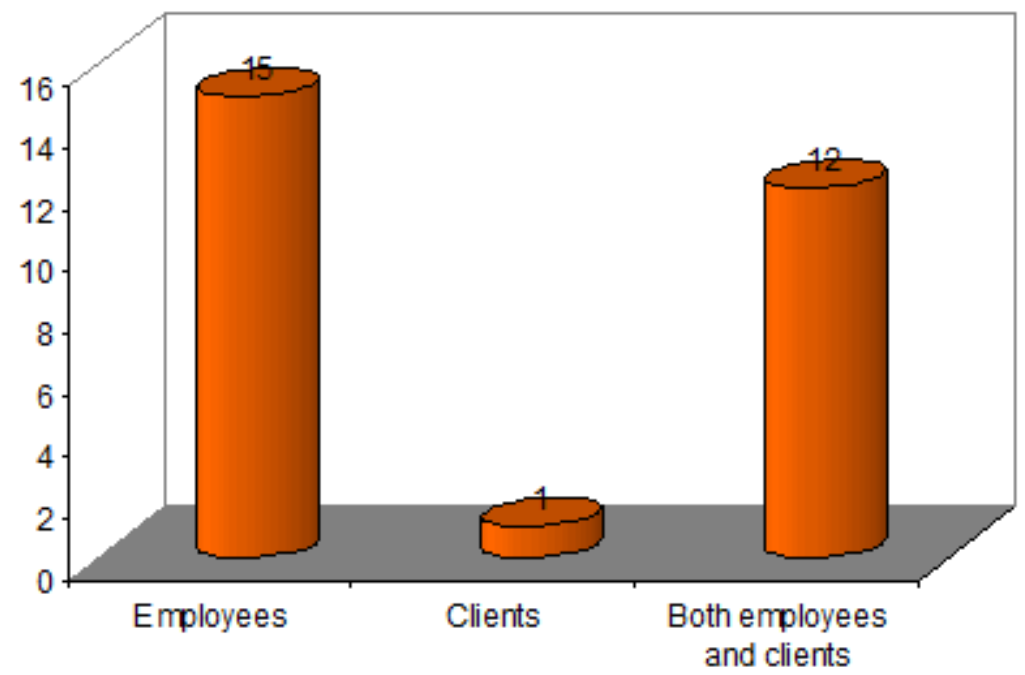

Figure 2: Education of employees and/or clients 
$\%$ of companies educate their clients only (Figure 2). The purpose of educating clients is a wish to introduce them to the advantages of cooperation with the company, as well as teaching them about the most effective and efficient ways of using the products and services of the company that organizes education (Morrison \& Meister, 2001).

Partly confirming the appointed hypothesis, the results of the analysis suggest that despite their favorable attitude towards education companies in the Serbian market allocate modest resources for education, often only when the situation calls for it.

In the following segment of the survey, we shall present the analysis of utilization of modern Information Technologies (Videoconferencing systems) in education and meetings.

A major prerequisite for the application of videoconferencing in education and meetings is a permanent Internet access facility (Beogradska Otvorena Skola, 2009). The fact that all companies participating in the survey satisfy the requirement, which corresponds to some earlier studies, is encouraging (Belgrade Open School, E-gate) (E-kapija, 2009).

The introduction of videoconferences into business is sensible if there is a necessity for virtual lectures and/or meetings in form of supplementary activities, and if traditional forms of education can/are needed to be replaced (Kay, 1991).

In companies, lectures are mainly run through occasional courses, which occurs rarely in $36.7 \%$ companies, frequently in $26.7 \%$ and when needed in $23.3 \%$ of the surveyed companies. The courses are given either very rarely or are never organized in $13.3 \%$ of the companies. As opposed to this, there is an almost unbelievable fact that $74 \%$ of leading American companies that took part in the survey in 2009, have planned to increase the number (which is already considerably high) of the courses intended for employee education (The Future of Learning \& Development, 2009).

In Serbia, courses are most commonly organized in telecommunication and informatics companies, which is not surprising, as these are subject to constant development and advancement. Similarly, in this respect, the sectors of sale and foreign companies' representation are keeping up with current education trends (Table 2).

Table 2: Course frequency

\begin{tabular}{|c|c|c|c|c|c|c|}
\hline SECTOR & NEVER & $\begin{array}{c}\text { VERY } \\
\text { RARELY }\end{array}$ & RARELY & FREQUENTLY & $\begin{array}{c}\text { VERY } \\
\text { FRQUENTLY }\end{array}$ & TOTAL \\
\hline Services & & & $66.6 \%$ & $33.4 \%$ & & 3 \\
\hline $\begin{array}{l}\text { Import, Service } \\
\text { Delivery and Sale, } \\
\text { Representation }\end{array}$ & $11.1 \%$ & $11.1 \%$ & $22.2 \%$ & $33.3 \%$ & $22.3 \%$ & 9 \\
\hline Production & & & $42.9 \%$ & $42.9 \%$ & $14.2 \%$ & 7 \\
\hline $\begin{array}{l}\text { Telecommunication } \\
\text { and Information } \\
\text { Systems }\end{array}$ & & $16.7 \%$ & $33.3 \%$ & & $50 \%$ & 6 \\
\hline $\begin{array}{l}\text { Banking, Financing } \\
\text { and Insurance }\end{array}$ & & $20 \%$ & $40 \%$ & $20 \%$ & $20 \%$ & 5 \\
\hline $\begin{array}{c}\text { TOTAL } \\
\text { NUMBER OF } \\
\text { RESPONDENTS: }\end{array}$ & & & & & & 30 \\
\hline
\end{tabular}


Since the survey infers that the majority of companies organize courses, the query concerning the form of the course gave the following results: $30 \%$ of the companies provide opportunities solely for traditional courses, whereas in $66.7 \%$ of companies these are available both online and via videoconferences (Table 3). These facts suggest that the companies in the Serbian market do not fall much behind the companies in more economically developed countries, at least, in theory. Namely, the survey carried out in more than 60 American companies shows that $62 \%$ of the participants plan to perform the biggest part of employee educational process in future by using contemporary technologies, like Internet and videoconferencing (3D Learning and Virtual Worlds, 2009).

Table 3: Traditional vs. videoconference-based lectures

\begin{tabular}{|l|r|r|}
\hline \multicolumn{1}{|c|}{ TRADITIONAL VS. VIDEOCONFERENCE LECTURES } & TOTAL & \multicolumn{1}{c|}{$\%$} \\
\hline Only traditional & 9 & 30 \\
\hline Videoconference lectures are also available & 20 & 66.7 \\
\hline Query not answered & 1 & 3.3 \\
\hline \multicolumn{1}{|c|}{ TOTAL NUMBER OF RESPONDENTS: } & $\mathbf{3 0}$ & $\mathbf{1 0 0 \%}$ \\
\hline
\end{tabular}

Understanding advantages of videoconferencing is the essential prerequisite for its incorporation into business. Attending lectures from a workplace is both practical and economical, is the opinion of $90 \%$ respondents. Besides, there are a great many additional advantages that respondents put forward (Table 4).

Table 4: Advantages of online courses

\begin{tabular}{|l|r|r|r|r|}
\hline \multicolumn{1}{|c|}{ ADVANTAGE } & \multicolumn{1}{c|}{ YES } & \multicolumn{1}{c|}{ NO } & \multicolumn{1}{c|}{ YES (\%) } & \multicolumn{1}{c|}{ NO (\%) } \\
\hline Higher productivity & 15 & 15 & 50 & 50 \\
\hline Greater competence & 14 & 16 & 46.7 & 53.3 \\
\hline Increased self-confidence & 9 & 21 & 30 & 70 \\
\hline Feeling of belonging & 12 & 18 & 40 & 76.7 \\
\hline Promotion opportunities & 9 & 23 & 23.3 & 70 \\
\hline Increased motivation & 14 & 16 & 46 & 53.3 \\
\hline $\begin{array}{l}\text { Knowledge-induced feeling of satis- } \\
\text { faction }\end{array}$ & & 21 & 46.7 & \\
\hline
\end{tabular}

In the survey, higher productivity obtained through videoconferences and classical online courses are most commonly recognized as the greatest advantage (50\%). The fact that additional education through online courses provides promotion in only $23.3 \%$ of companies leaves space for worry. Hence, it is not surprising only $30 \%$ of respondents find frequent online courses stimulating.

Participants in the study were also asked to comment on which online courses are major - 'by order' courses or available commercial and/or free ones or courses created by employees. Some $96.7 \%$ of respondents gave answer to the query, whereby $65.5 \%$ opted for the 'by order' courses. The result is the indicative of the above mentioned hypothesis. Namely, companies are asked about the online courses they would run, not about those they are already running. As regards the engagement of external institutions in staff education, $56.7 \%$ of respondents reply that they are 
using services of external institutions. However, the very fact that $65.5 \%$ of respondents are interested in the services and would engage in the courses undoubtedly reflects the economic crisis that companies in Serbian market are facing.

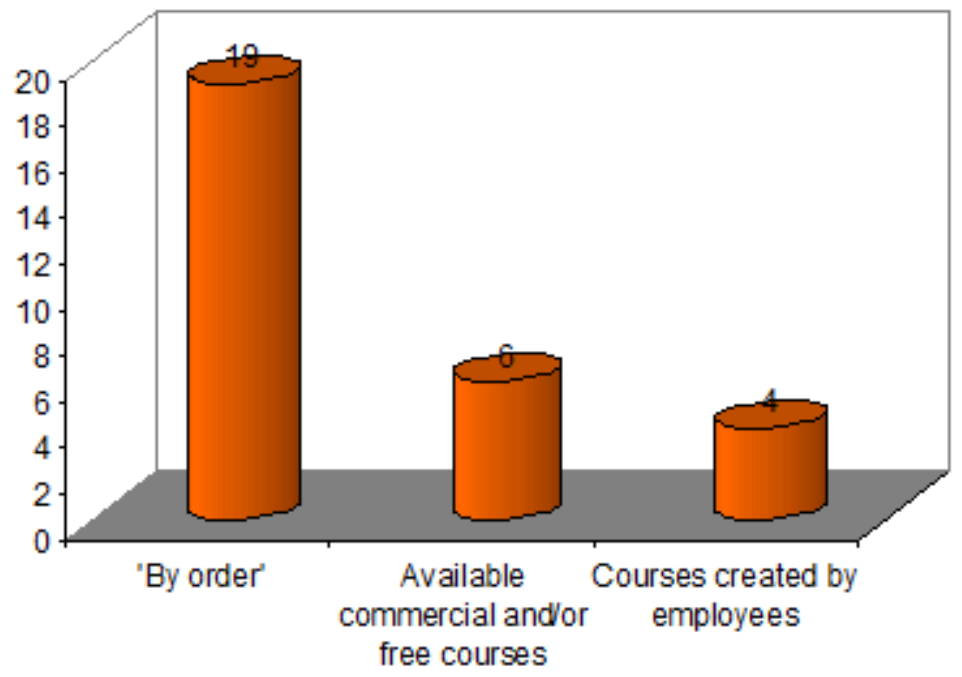

Figure 3: Online courses selection

Some $86.7 \%$ of respondents in the survey believe that attending meetings from a workplace is doubtless a great advantage of videoconferencing. Bearing in mind that in the surveyed companies managers attend meetings often or very often ( $50 \%$ and $26.7 \%$ respectively), videoconferencing could undoubtedly be applied in organizing meetings either inside a company or among companies, whereby one should pre-determine which section of a meeting can be organized using the above technology.

Some $83.3 \%$ of respondents believe that a number of meetings could be virtual, which points to promising prospects of videoconferencing (Figure 4).

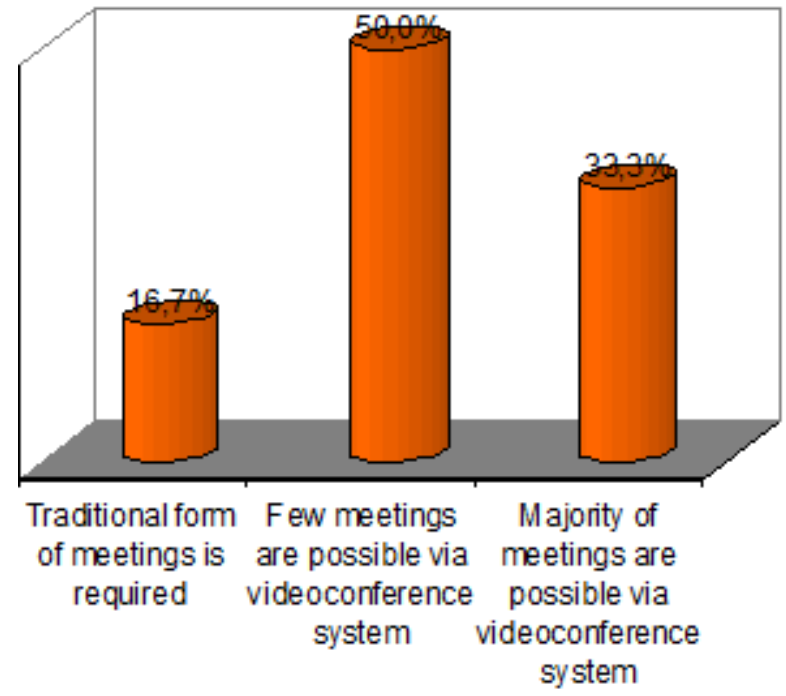

Figure 4: Availability of virtual meetings

Besides expressing their opinions on technical possibilities of running virtual meetings, respondents also included comments on technical possibilities for running virtual process simulation, simulation of device operation, and installation and device operation procedures (Table 5). The 
answers were mostly positive, which further encourages the introduction of videoconferences and newly developed systems into business practice of companies in the Serbian market. The importance of practical simulation and exercises can best be seen in the survey carried out in the USA in 2008. Namely, in 1986, an employee on average needed $75 \%$ of theoretical and $25 \%$ of practical knowledge in order to do their work properly. The survey from 2008, mentioned above, shows that now an employee needs $8-10 \%$ of theoretical and more than $90 \%$ of practical knowledge to do their work properly (Clarke \& Jennings, 2009). The advantages of the use of VC systems in these processes are beyond doubt, beginning with cost reduction and an increase in productivity, to implementing practical exercises in authentic environment, or, in other words, at a place where the knowledge will also be used practically.

Table 5: Application of VC system

\begin{tabular}{|l|r|r|r|r|}
\hline \multicolumn{1}{|c|}{ APPLICATION } & \multicolumn{1}{|c|}{ YES } & \multicolumn{1}{c|}{ NO } & \multicolumn{1}{c|}{ YES (\%) } & \multicolumn{1}{c|}{ NO (\%) } \\
\hline Virtual meetings (See Figure 4) & 25 & 5 & 83.3 & 16.7 \\
\hline Virtual simulation of device operation & 22 & 8 & 73.3 & 26.7 \\
\hline Virtual process simulation & 22 & 8 & 73.3 & 26.7 \\
\hline $\begin{array}{l}\text { Virtual simulation of installation and } \\
\text { device operation procedures }\end{array}$ & 22 & 8 & 73.3 & 26.7 \\
\hline
\end{tabular}

The questions above refer to the hypothetical application of videoconferences, or rather whether or not videoconferences could be applied or not. From the theoretical aspect, current state corresponds to the first part of the appointed hypothesis, i.e. an averagely successful company in the Serbian market gives modest allocations for staff education, has a positive attitude towards the education and believes in wider application of videoconferences in everyday business. Therefore, we can shift towards the second part of our hypothesis which argues that the results of the investigation prove that the majority of companies have not yet had an opportunity for the application of videoconferences, but recognizing the importance and advantages of the systems have planned to take an initiative for their introduction as soon as the resources have been provided.

As regards how knowledgeable they are about advantages of videoconferences, respondents were encouraged to assess them $(1-5)$. Although the average grade was $M=3.40$ it varied among sectors (Table 6). As expected, the sectors of Telecommunications and Information Systems, which, in character, are closely related to modern technologies, gave the best results - all respondents were acquainted with advantages of videoconferencing (graded 4-5). In conclusion, table 6 shows that all sectors are mostly acquainted with advantages of the above systems, which is a favorable precondition for their introduction into business practice.

Table 6: Acquaintance of respondents with advantages of videoconference system (by sectors)

\begin{tabular}{|l|c|c|c|c|c|}
\hline \multicolumn{1}{|c|}{ SECTOR } & $\mathbf{1}$ & $\mathbf{2}$ & $\mathbf{3}$ & $\mathbf{4}$ & \multicolumn{1}{c|}{$\mathbf{5}$} \\
\hline Services & & $33.4 \%$ & & & $66.6 \%$ \\
\hline $\begin{array}{l}\text { Import, Service Delivery and Sale, } \\
\text { Representation }\end{array}$ & $22.2 \%$ & $22.2 \%$ & $22.2 \%$ & $33.4 \%$ & \\
\hline Production & & $14.2 \%$ & $42.9 \%$ & $42.9 \%$ & $50 \%$ \\
\hline $\begin{array}{l}\text { Telecommunications and Informa- } \\
\text { tion Systems }\end{array}$ & $20 \%$ & $20 \%$ & & $40 \%$ & $20 \%$ \\
\hline Banking, Financing and Insurance & & & $50 \%$ \\
\hline
\end{tabular}


In addition, the research included the issue of practical application of videoconferences, or rather, whether or not, and to what extent, videoconferences are used in companies operating in the Serbian market. Some $40 \%$ of companies included in the survey have experienced the application of videoconferencing, whereas from the rest $60 \%$ (18 companies), 14 of them $(77.7 \%)$ are planning to introduce the system (Table 7).

Table 7: Companies that are not using, but are planning to use videoconferences (\%)

\begin{tabular}{|c|c|c|c|c|}
\hline Sector & Yes & No & Yes $(\%)$ & No (\%) \\
\hline Services & 1 & 1 & 50 & 50 \\
\hline $\begin{array}{l}\text { Import, Service Delivery and Sale, } \\
\text { Representation }\end{array}$ & 5 & 2 & 71.5 & 28.5 \\
\hline Production & 3 & & 100 & 0 \\
\hline $\begin{array}{l}\text { Telecommunications and Informa- } \\
\text { tion Systems }\end{array}$ & 3 & & 100 & 0 \\
\hline Banking, Financing and Insurance & 2 & 1 & 66.6 & 33.4 \\
\hline Total number of respondents & 14 & 4 & $77.7 \%$ & $22.3 \%$ \\
\hline
\end{tabular}

The survey also examines to what extent the education of employees, aimed at easier application of videoconferences and providing access to these systems, affects the admission of the idea among employees. Ten companies (83.3\%) out of 12 already using the systems regard staff education a necessity. Similarly, even a larger number of companies $(91.7 \%)$ believe that simple attitude of employees to these systems greatly encourages employees to use videoconferences. As regards 14 companies that are to introduce videoconferencing into their business, they understand to a great extent how the knowledge on importance of education $(85.7 \%)$ and simplicity of these systems (78.6\%) can influence easier admission of the systems among employees (Table 8).

Table 8: Employees' acceptance of videoconferences as influenced by the education thereon (in companies that are planning to introduce videoconferencing)

\begin{tabular}{|l|r|r|r|r|}
\hline \multicolumn{1}{|c|}{ ACTIVITY } & NECESSARY & $\begin{array}{c}\text { ACTIVITY } \\
\text { HAS NO } \\
\text { EFFECT }\end{array}$ & $\begin{array}{c}\text { NECESSARY } \\
(\%)\end{array}$ & $\begin{array}{c}\text { ACTIVITY } \\
\text { HAS NO } \\
\text { EFFECT ( \% ) }\end{array}$ \\
\hline Education of employees & 12 & 2 & 85.7 & 14.3 \\
\hline Simple use & 11 & 3 & 78.6 & 21.4 \\
\hline
\end{tabular}

The results obtained from the final question in the survey confirm the second part of our hypothesis, i.e. companies in the Serbian market are recognizing advantages of videoconferencing and are planning to introduce them into their business practice (no fewer than $93.3 \%$ of all companies in the survey) (Figure 5). 


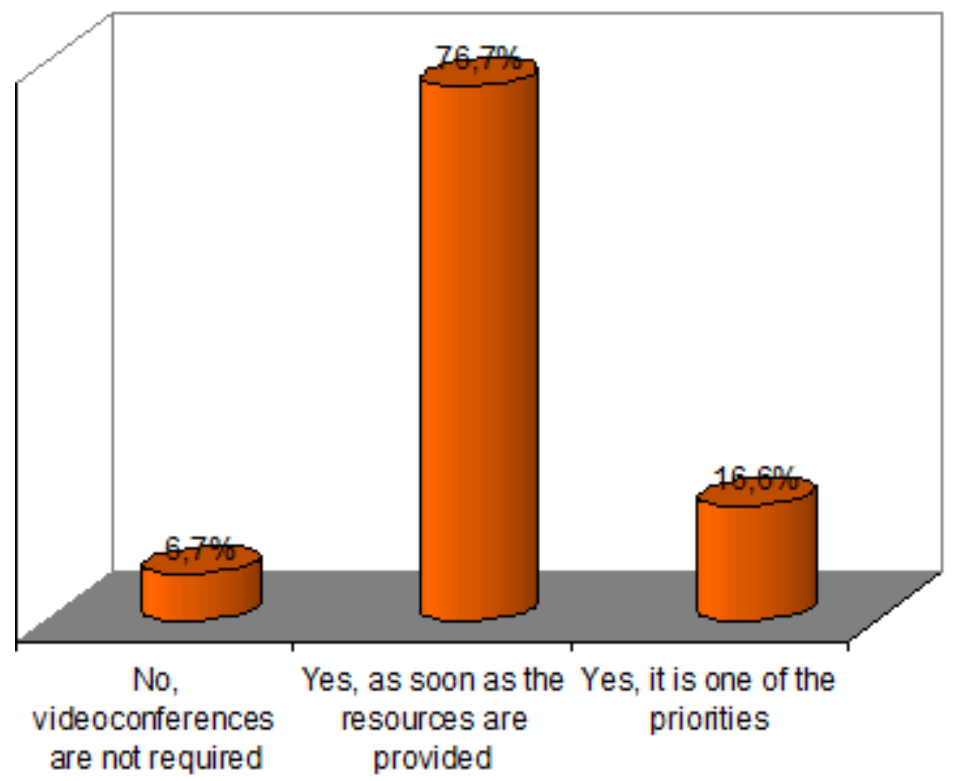

Figure 5: The plan of introduction of videoconferences into business practice

Videoconferencing has numerous advantages that encourage authorized persons inside companies for the introduction of the above technology:

- While attending virtual lectures, participants are focused on lecture material, $76.7 \%$ of respondents believe (Numerous investigations suggest that in traditional lectures, employees are under pressure due to the necessity of leaving office and traveling to other towns or countries where lectures are held bring more stress than the very learning process (Brodie \& McLean, 1995).

- Videoconferencing provides persons across land to follow lectures from their workplace, which not only eliminates travel expenses but also increases productivity. In addition to this, a big advantage of learning in the workplace is the fact that employees learn in authentic environment, actually, environment where they will also use the acquired knowledge (Polley-Berte, 2009). In addition, a rise in the number of participants in the lectures does necessarily result in higher training costs (Senge, 1990), believe $90 \%$ of participants in the survey.

- Frequent virtual meetings with suppliers and clients contributes to strengthening business relations and co-operation, believe $73.3 \%$ of participants in the survey.

- Introduction of videoconferences into communication of employees who are spatially distant from their leaders has positive effect on business, as communication and travel costs are substantially reduced, and higher productivity is ensured through communication from office. Some $90 \%$ of respondents agree with the statement.

- When an employee is in two minds about any issue, he/she can ask for advice from their colleagues or superiors who are better instructed in respective field. This doubtless adds up to the quality of service delivery and maintains business costs lower (Spencer, 2006), believe $86.7 \%$ of respondents.

- Some $73.3 \%$ of respondents said that the introduction of videoconferencing contributes greatly to the general image of a company which comes over as keeping up with modern technology trends, which further improves its position in the market. 
The above results fully support the pre-set objectives, i.e. the attitude of companies towards corporate learning, the investigation into potential replacement of traditional forms of meetings and lectures with modern communication modes and online education with particular reference to the application of videoconferences in the process. Similarly, we were also investigating how knowledgeable companies are about the named technology and their attitude to its potential introduction into everyday business. The fact that data processing has attained the major objective of the research -confirmation of the proposed hypothesis, is of particular importance. In other words, the research has confirmed that the application of online education and virtual training in corporate learning can yield important advantages in business management.

\section{Conclusion}

Despite the fact that companies recognize the necessity of keeping up with current trends and advantages of permanent education of their employees, the fact that Serbian companies are operating under the circumstances of economic crisis should not be overlooked. As a matter of fact, every third company has departments in charge of staff education, whereas it is only in a narrow majority of companies participating in the survey that the education issue is assigned to a single person. Similarly, the indicative of current crisis is the fact that only $55.5 \%$ of the companies have specialized education departments, whereas in the rest education issues are considered as an additional activity of certain departments. As regards companies where education is assigned on a personal scale, only $18.7 \%$ of companies regard education as a primary activity while the rest $(81.3 \%)$ consider it as an additional activity. With regard to the above stated and the fact that only modest resources are allocated for education purposes, only when situation calls for it, we can draw a conclusion that companies in Serbia have recognized the importance of education, nevertheless the shortage in resources is the major limiting factor for establishing permanentbasis education. On the other hand, companies in developed countries, like the USA, have suitable conditions that enable them to invest into education as much as they need. In accordance with this goes the fact that in the USA investments in staff education increase on the average every year, while the highest growth was registered in 2006 (an increase of 7\% in regard to 2005) (Bersin, 2007).

The fact that a large number of respondents are knowledgeable about advantages of online training and videoconferencing is rather encouraging. Besides lower costs and enhanced productivity, application of modern technology and improving quality of service delivery are emphasized as principal advantages that render a more attractive image of a company. The research confirmed that $66.7 \%$ of companies are equipped for videoconference-based lectures, whereas even $83.3 \%$ of companies believe that meetings can be held via the same technology. The results, which include the above facts and that only $6.7 \%$ of companies find introduction of videoconferences unnecessary, suggest that companies operating in the Serbian market understand advantages of application of the above systems, but low resources come out as the limiting factor.

However, $40 \%$ of the surveyed companies found a manner of overcoming the problem and they managed to apply videoconferences in their business, which helped them to practically become familiar with advantages of the systems. Companies which have not yet had opportunities to implement these systems are showing interest in introducing them in everyday business $(77.7 \%)$.

In conclusion, the performed research infers that the Serbian market is open to videoconferences, as even $93.3 \%$ of respondents are planning to introduce these systems (16.6\% of the companies are to implement them into their business in the near future, and $76.7 \%$ in the foreseeable future, as soon as the resources are provided).

Bearing in mind the fact that videoconference technology is still in the transition phase and is gradually being introduced into Serbian market, as well as the fact that companies are becoming 
aware of advantages of the above technology, it would be beneficial to repeat the research so as to gain an insight into the current state concerning the introduction of the technology into business.

In addition, as this issue has not been given sufficient attention by a wider community of West Balkan, it would be beneficial to conduct another survey which could provide a deeper insight into the corporate learning attitudes in the region of the Western Balkans.

\section{References}

3D Learning and Virtual Worlds. (2009). Retrieved February 2, 2010 from http://www.trainingindustry.com/media/2043910/acs $\% 203 \mathrm{~d} \% 20$ worlds $\% 20$ and $\% 20$ virtual $\% 20$ learnin g_whitepaper\%20april\%202009.pdf

Beogradska Otvorena Skola [Belgrade Open School]. (2009). Retrieved November 21, 2009, from http://www.bos.rs/

Bersin J. (2007). Top trends in e-learning and corporate training. HR Management Magazine, Issue 5. Retrieved February 2, 2010 from http://www.hrmreport.com/article/Top-trends-in-e-learning-andcorporate-training/

Boord M. P. (1997). Video teletraining: A guide to design, development, and use. SAD.

Brodie, M., \& McLean, N. (1995). Process reengineering in academic libraries: Shifting to client-centered resource provision. Cause/Effect, 18.

Clarke D. J., \& Jennings C. (2009). Experiential learning: Bringing knowledge to life. Retrieved February 2, 2010 from http://toolwire.com/files/ExperientialLearning.pdf

E-kapija [E-gate]. (2009). Retrieved November 22, 2009, from http://www.ekapija.com/

Kay, A. C. (1991). Computers, networks and education. SAD: Scientific American, 265.

Knowledge in organizations: Resources for the knowledge-based economy. (1997). Boston: ButterworthHeinemann.

Meister, C. J. (2007). Training / E-Learning: Web-based corporate learning takes off. Human Resource Executive Online Magazine. Retrieved February 2, 2010 from http://www.hrexecutive.com/HRE/story.jsp?storyId=46955614

Morrison, L. J., \& Meister, C. J. (2001). e-Learning in the corporate university: An interview with Jeanne Meister. Retrieved February 2, 2010 from http://technologysource.org/article/106/

Njeguš, A., \& Veljović, A. (2004). Internet poslovno programiranje [Internet Business Programming]. Belgrade, Megatrend University of Applied Sciences

Polley-Berte M. (2009). Improving on-the-job training with LMS and e-Learning tools. The New Learner. Retrieved February 2, 2010 from http://thenewlearner.com/2009/05/29/improving-on-thejob-training-with-lms-and-e-learning-tools/

Rosenberg J. M. (2008). E-learning strategies for delivering knowledge in the digital age. McGraw-Hill.

Senge, M. P. (1990). The fifth discipline: The art and practice of the learning organization. New York: Doubleday.

Spencer, B. (2006). The purposes of adult education: A short introduction. Toronto: Thompson Educational Publishing Inc.

The Future of Learning \& Development. (2009). Retrieved February 2, 2010 from http://www.trainingindustry.com/media/2462010/futurethinkfuture $\% 20 \mathrm{of} \% 20$ learning $\% 20 \mathrm{and} \% 20$ development.pdf

White Paper: Real Sales Success Delivered Virtually. (2009). Retrieved February 2, 2010 from http://www.trainingindustry.com/media/1961968/20081210\%20the\%20tas\%20group\%20white\%20pa per $\% 20-\% 20$ sales $\% 20$ effectiveness $\% 20$ delivered $\% 20$ virtually $\% 20$ december $\% 202008$.pdf 


\section{Biographies}

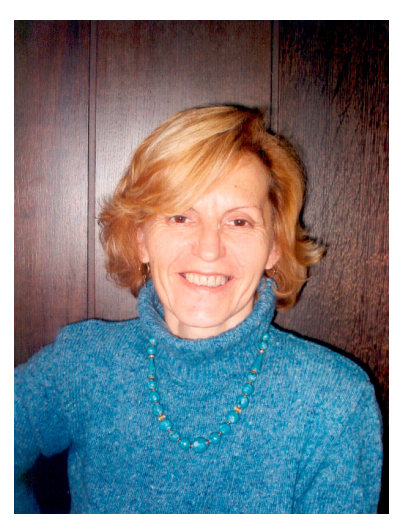

Dr Radojka Krneta is Associate Professor at the Technical Faculty Cacak, University of Kragujevac. She holds B.Sc. in Electronic Engineering at Faculty of Electronic Engineering, University of Nis, M.Sc. in Technical Science at Faculty of Electrical Engineering, University of Belgrade and Ph.D. in Technical Science at Technical Faculty, Cacak, University of Kragujevac in the field of digital signal processing. Her research and pedagogic interests are Computer Technology, Digital Signal processing, Digital Control Systems, Energy efficiency and Infrastructure of E-learning Environments. She is autor/co-autor of over 80 research papers, 3 students textbooks and head of several national and international research project. She was head of the bilateral project (cooperation with FERI Faculty, University of Maribor) "Plan of the strategy for the development and application of the electronic education in Serbia and Montenegro", 2006-2008. She is Grant-coordinator of TEMPUS JEP-2006 project M.Sc. Curriculum in E-Learning, (2007-2009). http://www.tfc.kg.ac.yu/tempus-jep-41016-2006/. and Coordinator of the WUS MSDP project "Master in Remote Control", WUS Austria, 2009-2010. She is head of multimedia laboratory E-lab at Technical Faculty Cacak.

Contact Information: University of Kragujevac, Technical Faculty Cacak, Svetog Save 65, 32000 Cacak, Serbia. e-mail: radojka@tfc.kg.ac.rs, rkrneta@gmail.com www: http://www.tfc.kg.ac.rs/r krneta

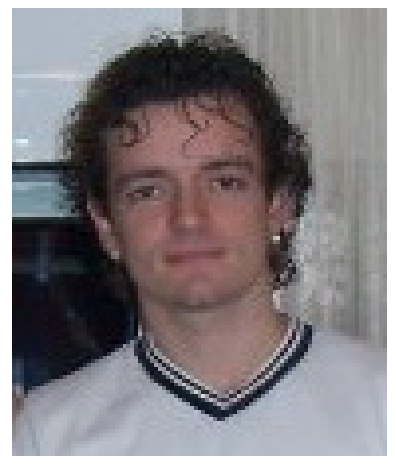

Vladimir Zocevic is employee of Agromehanika service on Cacak. He holds BSC in Economics, specialised for computer engineering. He is Master of Technical Science, at Technical Faculty, Cacak, University of Kragujevac in the field of information's technology. His researches and professional interests are e - learning, corporate learning, the practical use of videoconferences, the possibility of videoconference application in the corporate purposes, the preparation and organization of virtual meetings. He is author / co - author of few research papers, published in conferences of domestic and international importance.

Contact Information: Agromehanika service, Spomen park bb, 32000 Cacak, Serbia. email: obilics@yahoo.com 